\title{
The effect of concentrate supplementation on the productivity of grazing Jersey cows on a pasture based system
}

\author{
R. Meeske ${ }^{1 \#}$, A. Rothauge ${ }^{2}$, G.D. van der Merwe ${ }^{1}$ and J.F. Greyling ${ }^{1}$ \\ ${ }^{1}$ Department of Agriculture, Western Cape, Outeniqua Experimental Farm, P.O. Box 249, George 6503, South Africa \\ ${ }^{2}$ Neudamm Agricultural College, PB 13188, Windhoek, Namibia
}

\begin{abstract}
The effect of concentrate feeding on milk production, milk composition, live weight, condition score and intercalving period of 60 Jersey cows grazing high quality pastures over two lactations was determined. Cows were fed at a no (NC), low (LC), medium (MC) or high (HC) level of concentrate. All cows received a mineral supplement of $300 \mathrm{~g} /$ day. The LC, MC and HC groups were fed an energy concentrate at 3, 6 and $9 \mathrm{~kg} / \mathrm{day}$, respectively from day 1 to day 150 of lactation followed by $1.5,3$ and $4.5 \mathrm{~kg}$ of energy concentrate per day from day 151 to day 300 of lactation. The energy concentrate consisted of $10.6 \%$ whole cottonseed, $42.1 \%$ rolled maize, $42.1 \%$ rolled wheat, $4.2 \%$ molasses, $0.5 \%$ feedlime and $0.5 \%$ salt on a dry matter (DM) basis. A protein concentrate consisting of $76.5 \%$ cotton oil cake and $23.5 \%$ fish meal was fed at $0.5,1$ and $1.5 \mathrm{~kg}$ per day to the LC, MC and HC group respectively from days 1 to 105 of lactation. The lactating cows grazed pasture allocated at $20 \mathrm{~kg} \mathrm{DM} / \mathrm{cow} /$ day consisting of 43\% perennial ryegrass/clover, $24 \%$ annual ryegrass/oats, $14 \%$ lucerne, $15 \%$ kikuyu and $4 \%$ other pastures during the experimental period. The fat corrected milk (FCM) production per lactation of cows fed NC ( $0 \mathrm{~kg} /$ day), LC (2.4 kg/day), MC (4.8 kg/day) and HC (7.2 kg/day) was 3741, 4645, 4868 and $5282 \mathrm{~kg}$ (s.e.m. = 146), respectively. Cows fed the high level of concentrate $(\mathrm{HC})$ produced significantly more FCM and butterfat than cows on the other treatments. The FCM production of cows on the LC and MC treatments did not differ from each other and both produced more FCM than the control treatment. Cows produced 1.25, 0.78 and $0.54 \mathrm{~L}$ of FCM for each $\mathrm{kg}$ of concentrate fed at the LC, MC, and HC levels of concentrate feeding over two lactations. Concentrate feeding had no significant effect on milk composition, live weight and intercalving period of cows. The condition score of cows improved as the level of concentrate feeding increased.
\end{abstract}

Keywords: Milk production, milk composition, grazing, intercalving period, condition score, live weight change, pasture quality

${ }^{\#}$ Corresponding author. E-mail: robin@elsenburg.com

\section{Introduction}

Pasture is the base for profitable milk production in the Southern Cape region of South Africa. Energy intake is the first limiting factor for milk production in cows grazing on pasture (Kolver, 2003), including perennial ryegrass/white clover, annual ryegrass and oat pastures. Concentrates are supplemented to cows grazing on pasture to increase the stocking rate, increase milk production, maintain body condition and improve the profitability of dairy farming (Bargo et al., 2003). The cost of pasture in the Southern Cape may vary from $\mathrm{R}$ 0.20 to R 0.60 per kg dry matter (DM) and that of dairy concentrate from R 0.80 to R 1.80 per $\mathrm{kg} \mathrm{DM}$. Concentrates often constitute $66 \%$ of the total feed cost and pasture $34 \%$ (W.J. Burger; Personal communication, Outeniqua Experimental Farm, P.O. Box 249, George, 6530). The level of concentrate feeding and the associated milk production response have a major effect on the profitability of pasture based dairy farming. It is therefore important to determine the optimum level of concentrate supplementation. The milk response to concentrate fed to cows on a pasture based system is affected by pasture quality, pasture allowance, nutritional value of the concentrate, level of concentrate feeding and the genetics of the cow (Bargo et al., 2003). The milk response per $\mathrm{kg}$ concentrate fed tends to decline as pasture allowance is increased (Grainer \& Mathews, 1989) and the level of concentrate feeding is increased (Robaina et al., 1998). A high pasture allowance results in poor pasture utilization, lower stocking rates and reduced profit per hectare. The substitution rate by which concentrate replaces pasture is greater at a high pasture allowance and therefore the response to concentrate feeding will be lower (Bargo, 2002).

King et al. (1990) found that cows produced only $0.6 \mathrm{~kg}$ milk/kg of concentrate, when fed at 3.5 
$\mathrm{kg} / \mathrm{cow} / \mathrm{day}$. The aim of this study was to determine the long-term effect of concentrate supplementation on milk yield, milk composition, live weight, condition score and intercalving period of Jersey cows grazing on a pasture based system in the Southern Cape region of South Africa.

\section{Materials and Methods}

The study was done at the Outeniqua Experimental farm, George (longitude $22^{\circ} 25^{\prime} \mathrm{E}$, latitude $33^{\circ} 57^{\prime} \mathrm{S}$, altitude $190 \mathrm{~m}$ ). The long term (30 year) average rainfall is $715 \mathrm{~mm}$ per annum. Monthly rainfall is $60 \mathrm{~mm}, 64$ $\mathrm{mm}, 52 \mathrm{~mm}$ and $62 \mathrm{~mm}$ during summer, autumn, winter and spring, respectively. Pasture was irrigated at 750 $\mathrm{mm}$ per annum according to tensiometer readings, to keep tensiometer readings between -10 and $-25 \mathrm{kPa}$. Average daily maximum and minimum temperatures are 24 and $15{ }^{\circ} \mathrm{C}$ during summer, 22 and $12{ }^{\circ} \mathrm{C}$ during autumn, 19 and $7{ }^{\circ} \mathrm{C}$ during winter and 20 and $11^{\circ} \mathrm{C}$ during spring, respectively (Weather SA, 2004).

Sixty Jersey cows were randomly allocated to four treatments ( 15 cows per treatment). Cows remained in their groups for two consecutive lactations. Heifers were assigned to groups at random by order of calving. Multiparous cows were blocked according to milk yield in their most recently completed lactation and then randomly assigned to treatments as they calved. Calving took place over an extended period of six months. All cows were dried up 60 days before the expected calving date. Milk production was measured daily over 300 days of lactation. Milk samples were taken monthly, preserved with sodium dichromate, stored in containers and sent to the laboratory to be analysed for milk fat and protein content with a 605 Milko Scan analyzer, a midrange infrared spectrophotometer (IDF, 1996). The pasture grazed during the three years of the study consisted of $43 \%$ perennial ryegrass/clover, $24 \%$ annual ryegrass/oats, $14 \%$ lucerne, $15 \%$ kikuyu and $4 \%$ other pastures. Twenty kg of pasture DM was offered per cow per day to ensure that sufficient pasture was available. Pasture yield before grazing was estimated by cutting 10 representative randomly selected quadrants to ground level. Samples were oven-dried at $60^{\circ} \mathrm{C}$ for $72 \mathrm{~h}$ to determine the DM content, milled through a $1 \mathrm{~mm}$ sieve and stored in plastic jars pending chemical analyses. In vitro organic matter digestibility (IVOMD) was determined according to Tilley \& Terry (1963), neutral detergent fibre (NDF) and acid detergent fibre (ADF) according to Van Soest et al. (1991). The metabolisable energy (ME ) content was calculated according to the ARC (1984) and assumed to be equal to $18.4 \mathrm{x}$ IVOMD x 0.81 . Total nitrogen was determined by the Kjeldahl method (AOAC, 1995). The minerals $\mathrm{Ca}, \mathrm{P}, \mathrm{Na}, \mathrm{K}, \mathrm{Mg}, \mathrm{Fe}, \mathrm{Cu}, \mathrm{Zn}$ and $\mathrm{Mn}$ were determined using an inductively coupled plasma dry ashing method (ALASA, dry ashing 6.1.1, RevA/98) with an Iris Advantage Thermo elemental instrument according to Giron (1973). Selenium was determined using a Perkin-Elmer Model LS-2B Filter Fluorimeter (Koh \& Benson, 1993). Cows were fed a no (NC), low (LC), medium (MC) or high (HC) level of concentrate. All cows received a mineral/vitamin supplement of $300 \mathrm{~g} /$ day to supply $36 \mathrm{~g} \mathrm{Ca,} 24 \mathrm{~g} \mathrm{P}, 21 \mathrm{~g}$ Mg, 240 mg Fe,15 mg Co, 225 mg Cu, 300 mg Mn, 450 mg Zn, 7.5 mg I, 90000 IU vitamin A and 30 IU vitamin E per cow per day. The LC, MC and HC groups were fed an energy concentrate (13 MJ ME/kg DM, 130 $\mathrm{g} \mathrm{CP} / \mathrm{kg} \mathrm{DM}$ ) at 3, 6 and $9 \mathrm{~kg} /$ day respectively from day 1 to day 150 of lactation followed by $1.5,3$ and $4.5 \mathrm{~kg}$ energy concentrate per day from day 151 to day 300 of lactation. The energy concentrate consisted of $10.6 \%$ whole cottonseed, $42.1 \%$ rolled maize, $42.1 \%$ rolled wheat, $4.2 \%$ molasses, $0.5 \%$ feedlime and $0.5 \% \mathrm{NaCl}$ on a DM basis. A protein concentrate was fed at $0.5,1$ and $1.5 \mathrm{~kg}$ per day to the LC, MC and HC group, respectively, from day 1 to day 105 of lactation, to supplement quality protein during early lactation. The protein concentrate (10.6 MJ ME/kg DM, $480 \mathrm{~g} \mathrm{CP} / \mathrm{kg} \mathrm{DM}$ ) consisted of $76.5 \%$ cotton oil cake and $23.6 \%$ fish meal on a DM basis. The average amount of concentrate fed per day over the lactation was $0,2.4,4.8$ and $7.2 \mathrm{~kg}$ for the NC, LC, MC and HC, respectively. Milk yield was measured daily and milk composition, live weight and condition score (Mulvany, 1977) were determined monthly. All the cows grazed as one group. Cows were inseminated when on heat after 55 days in milk.

Analysis of variance was done, using SAS (1999) and a nonlinear regression was fitted to predict fat corrected milk production over a 300 day lactation: $\mathrm{Y}=\mathrm{a}+\mathrm{bx}{ }^{0.5}$.

\section{Results and Discussion}

The mean chemical composition of the different types of pastures grazed by the lactating cows during the experimental period is given in Tables 1 and 2. The average crude protein (CP) content of annual ryegrass, perennial ryegrass/clover and lucerne was higher than the nutritional requirement of high producing dairy cows. The CP content of annual ryegrass varied from 136 to $310 \mathrm{~g} / \mathrm{kg}$ DM. This large variation in CP indicates that regular analysis of grass samples should be done and the CP content of the concentrate should be adjusted 
accordingly to ensure that the protein requirement of cows is met. The DM content of the lucerne grazing was higher and the NDF content lower than that of annual ryegrass and perennial ryegrass/clover pasture, which makes it an excellent pasture crop. Kikuyu had the lowest digestibility (9.3 MJ ME/kg DM), the highest NDF content of $635 \mathrm{~g} / \mathrm{kg}$ DM and a Ca to P ratio of 1.3: 1. These are similar values to those reported by Reeves et al. (1996). The average potassium (K) concentration of kikuyu, annual ryegrass and perennial ryegrass/clover was higher than $30 \mathrm{~g} / \mathrm{kg} \mathrm{DM}$. This high $\mathrm{K}$ concentration may lead to a reduction in Ca and $\mathrm{Mg}$ absorption (Underwood, 1981).

Table 1 Mean ( \pm s.d.) seasonal chemical composition (DM basis) of pastures at point of grazing, sampled during the experimental period over three years $(n=12)$

\begin{tabular}{|c|c|c|c|c|}
\hline \multirow[b]{2}{*}{ Nutrient composition } & \multicolumn{4}{|c|}{ Perennial ryegrass/clover } \\
\hline & Summer & Autumn & Winter & Spring \\
\hline $\mathrm{DM}$ (g/kg as is) & $163 \pm 17.6$ & $150 \pm 16.0$ & $153 \pm 18.4$ & $145 \pm 9.1$ \\
\hline Ash (g/ kg) & $90 \pm 15.3$ & $112 \pm 9.9$ & $110 \pm 4.4$ & $101 \pm 12.5$ \\
\hline $\mathrm{CP}(\mathrm{g} / \mathrm{kg})$ & $211 \pm 25.3$ & $236 \pm 16.4$ & $258 \pm 26.1$ & $207 \pm 44.7$ \\
\hline $\mathrm{ME}(\mathrm{MJ} / \mathrm{kg})$ & $9.9 \pm 0.29$ & $9.6 \pm 0.76$ & $10.7 \pm 0.77$ & $10.6 \pm 0.56$ \\
\hline $\mathrm{NDF}(\mathrm{g} / \mathrm{kg})$ & $476 \pm 45.9$ & $519 \pm 69.4$ & $436 \pm 69.5$ & $437 \pm 41.3$ \\
\hline \multirow[t]{2}{*}{$\mathrm{ADF}(\mathrm{g} / \mathrm{kg})$} & $301 \pm 13.7$ & $306 \pm 21.1$ & $256 \pm 26.3$ & $285 \pm 28.5$ \\
\hline & \multicolumn{4}{|c|}{ Annual ryegrass } \\
\hline Nutrient composition & Summer & Autumn & Winter & Spring \\
\hline $\mathrm{DM}$ (g/kg as is) & - & $119 \pm 18.8$ & $140 \pm 22.8$ & $147 \pm 36.2$ \\
\hline Ash (g/ kg) & - & $115 \pm 15.0$ & $100 \pm 16.5$ & $871 \pm 17.6$ \\
\hline $\mathrm{CP}(\mathrm{g} / \mathrm{kg})$ & - & $256 \pm 54.9$ & $251 \pm 62.7$ & $180 \pm 45.9$ \\
\hline ME (MJ/kg) & - & $9.5 \pm 1.37$ & $10.8 \pm 0.91$ & $10.9 \pm 0.63$ \\
\hline NDF (g/kg) & - & $510 \pm 85.1$ & $450 \pm 59.2$ & $490 \pm 62.3$ \\
\hline \multirow{2}{*}{$\operatorname{ADF}(g / k g)$} & - & $290 \pm 35.3$ & $241 \pm 34.4$ & $280 \pm 41.2$ \\
\hline & \multicolumn{4}{|c|}{ Kikuyu } \\
\hline Nutrient composition & Summer & Autumn & Winter & Spring \\
\hline $\mathrm{DM}$ (g/kg as is) & $187 \pm 48.6$ & $159 \pm 44.1$ & $168 \pm 28.5$ & $181 \pm 31.7$ \\
\hline Ash (g/ kg) & $88 \pm 26.0$ & $99 \pm 16.5$ & $106 \pm 10.2$ & $96 \pm 13.7$ \\
\hline $\mathrm{CP}(\mathrm{g} / \mathrm{kg})$ & $157 \pm 44.0$ & $196 \pm 57.1$ & $218 \pm 51.4$ & $176 \pm 42.2$ \\
\hline ME (MJ/kg) & $8.7 \pm 0.51$ & $8.4 \pm 0.60$ & $9.3 \pm 1.28$ & $9.7 \pm 0.93$ \\
\hline NDF (g/kg) & $682 \pm 57.2$ & $670 \pm 61.1$ & $592 \pm 115.3$ & $598 \pm 78.9$ \\
\hline \multirow[t]{2}{*}{$\mathrm{ADF}(\mathrm{g} / \mathrm{kg})$} & $322 \pm 39.3$ & $313 \pm 32.2$ & $271 \pm 39.4$ & $290 \pm 291$ \\
\hline & \multicolumn{4}{|c|}{ Lucerne } \\
\hline Nutrient composition & Summer & Autumn & Winter & Spring \\
\hline $\mathrm{DM}$ (g/kg as is) & $182 \pm 28.8$ & $188 \pm 28.0$ & $200 \pm 17.4$ & $199 \pm 17.9$ \\
\hline Ash (g/ kg) & $74 \pm 14.0$ & $97 \pm 27.8$ & $86 \pm 20.2$ & $73 \pm 12.2$ \\
\hline $\mathrm{CP}(\mathrm{g} / \mathrm{kg})$ & $215 \pm 32.5$ & $246 \pm 36.1$ & $257 \pm 25.6$ & $222 \pm 41.7$ \\
\hline ME (MJ/kg) & $9.3 \pm 0.39$ & $9.3 \pm 0.81$ & $10.6 \pm 0.87$ & $10.1 \pm 0.51$ \\
\hline NDF (g/kg) & $417 \pm 52.8$ & $430 \pm 39.1$ & $371 \pm 62.1$ & $410 \pm 48.7$ \\
\hline ADF (g/kg) & $321 \pm 31.2$ & $311 \pm 28.2$ & $262 \pm 36.3$ & $312 \pm 32.3$ \\
\hline
\end{tabular}

DM - Dry Matter; CP - Crude protein; ME - Metabolisable energy; NDF - Neutral detergent fibre;

$\mathrm{ADF}$ - Acid detergent fibre

The milk production, milk composition, live weight, condition score and intercalving period of cows fed different levels of concentrate over two lactations are presented in Table 3. The prediction of FCM production over a 300 day lactation using a non-linear equation is shown in Table 4. The milk production increased as the level of concentrate feeding increased. Cows fed the high level of concentrate (HC) produced significantly more fat corrected milk (FCM) and butterfat than cows on all the other treatments.

The yield of FCM, butterfat and protein on the NC treatment was lower than that of the LC and the MC treatments. Feeding of each additional kg of concentrate resulted in production of 1.25, 0.78 and $0.54 \mathrm{~kg}$ FCM 
Table 2 Mean ( \pm s.d.) mineral composition (DM basis) of pastures at point of grazing sampled during the experimental period of three years

\begin{tabular}{lrrrr}
\hline & Kikuyu & Ryegrass & Ryegrass / clover & \multicolumn{1}{c}{ Lucerne } \\
\cline { 2 - 5 } Mineral & $\mathrm{n}=20$ & $\mathrm{n}=24$ & $\mathrm{n}=24$ & $\mathrm{n}=20$ \\
\hline $\mathrm{Ca}(\mathrm{g} / \mathrm{kg})$ & $4.3 \pm 1.2$ & $6.7 \pm 2.1$ & $8.8 \pm 2.2$ & $11.9 \pm 2.7$ \\
$\mathrm{P}(\mathrm{g} / \mathrm{kg})$ & $3.3 \pm 0.8$ & $3.6 \pm 0.8$ & $4.0 \pm 1.0$ & $3.3 \pm 1.0$ \\
$\mathrm{Mg}(\mathrm{g} / \mathrm{kg})$ & $3.6 \pm 0.8$ & $3.6 \pm 1.1$ & $4.4 \pm 1.4$ & $3.7 \pm 1.5$ \\
$\mathrm{Na}(\mathrm{g} / \mathrm{kg})$ & $2.8 \pm 2.3$ & $8.9 \pm 6.2$ & $6.5 \pm 3.7$ & $3.1 \pm 1.1$ \\
$\mathrm{~K}(\mathrm{~g} / \mathrm{kg})$ & $30.4 \pm 9.4$ & $33.9 \pm 17.1$ & $30.1 \pm 11.6$ & $23.6 \pm 11.1$ \\
$\mathrm{Cu}(\mathrm{mg} / \mathrm{kg})$ & $8.0 \pm 2.6$ & $6.9 \pm 1.6$ & $8.1 \pm 1.7$ & $8.0 \pm 1.9$ \\
$\mathrm{Zn}(\mathrm{mg} / \mathrm{kg})$ & $43.9 \pm 7.3$ & $42.9 \pm 11.6$ & $44.4 \pm 7.1$ & $42.1 \pm 8.0$ \\
$\mathrm{Mn}(\mathrm{mg} / \mathrm{kg})$ & $79.8 \pm 36.4$ & $60.5 \pm 20.1$ & $63.4 \pm 24.5$ & $43.3 \pm 16.1$ \\
$\mathrm{Fe}(\mathrm{mg} / \mathrm{kg})$ & $196 \pm 133$ & $194 \pm 90$ & $360 \pm 215$ & $149 \pm 72$ \\
\hline
\end{tabular}

Table 3 Milk production, milk composition, live weight, condition score and intercalving period of cows fed different levels of concentrates over two lactations $(n=26)$

\begin{tabular}{|c|c|c|c|c|c|}
\hline \multirow[b]{2}{*}{ Parameters } & \multicolumn{4}{|c|}{ Concentrate level $^{\mathrm{f}}$} & \multirow[b]{2}{*}{ s.e.m. } \\
\hline & NC & LC & $\mathrm{MC}$ & $\mathrm{HC}$ & \\
\hline Concentrate fed/lactation (kg) & 0 & 720 & 1440 & 2160 & \\
\hline Milk production over 300 days (kg) & $3543^{c}$ & $4356^{\mathrm{b}}$ & $4565^{\mathrm{ab}}$ & $4885^{\mathrm{a}}$ & 142.3 \\
\hline FCM $^{\mathrm{e}}$ over 300 days $(\mathrm{kg})$ & $3742^{c}$ & $4645^{\mathrm{b}}$ & $4868^{b}$ & $5282^{\mathrm{a}}$ & 146.5 \\
\hline FCM kg/kg concentrate & - & 1.25 & 0.78 & 0.54 & \\
\hline Butterfat (kg) & $154^{\mathrm{c}}$ & $194^{\mathrm{b}}$ & $203^{b}$ & $222^{\mathrm{a}}$ & 6.2 \\
\hline Butterfat (\%) & 4.35 & 4.46 & 4.46 & 4.57 & 0.079 \\
\hline Protein (kg) & $125^{\mathrm{c}}$ & $155^{b}$ & $162^{\mathrm{ab}}$ & $174^{\mathrm{a}}$ & 4.9 \\
\hline Protein (\%) & 3.53 & 3.57 & 3.56 & 3.58 & 0.041 \\
\hline Live weight start of lactation (kg) & $383^{b}$ & $388^{\mathrm{ab}}$ & $383^{b}$ & $409^{\mathrm{a}}$ & 9.4 \\
\hline Live weight end of lactation (kg) & $416^{\mathrm{b}}$ & $421^{b}$ & $425^{\mathrm{ab}}$ & $446^{\mathrm{a}}$ & 7.96 \\
\hline Live weight change $(\mathrm{kg})$ & 33 & 33 & 42 & 37 & 7.3 \\
\hline Condition score start of lactation & $2.2^{\mathrm{b}}$ & $2.3^{\mathrm{b}}$ & $2.4^{\mathrm{b}}$ & $2.6^{\mathrm{a}}$ & 0.08 \\
\hline Condition score end of lactation & $2.1^{\mathrm{b}}$ & $2.2^{\mathrm{b}}$ & $2.5^{\mathrm{a}}$ & $2.6^{\mathrm{a}}$ & 0.095 \\
\hline Intercalving period (days) & $375^{\mathrm{a}}$ & $425^{b}$ & $383^{\mathrm{ab}}$ & $416^{\mathrm{b}}$ & 10.8 \\
\hline
\end{tabular}

\footnotetext{
${ }^{\mathrm{abc}}$ Row means with common superscripts do not differ $(\mathrm{P}>0.05) ;{ }^{\mathrm{d}}$ s.e.m. $=$ Standard error of mean;

${ }^{\mathrm{e}} \mathrm{FCM}=4 \%$ Fat corrected milk

${ }^{\mathrm{f}}$ Concentrate level: NC = No concentrate $0 \mathrm{~kg} / \mathrm{cow} /$ day, LC = Low concentrate $2.4 \mathrm{~kg} / \mathrm{cow} / \mathrm{day}, \mathrm{MC}=\mathrm{Medium}$ concentrate $4.8 \mathrm{~kg} / \mathrm{cow} /$ day, $\mathrm{HC}=$ High Concentrate $7.2 \mathrm{~kg} / \mathrm{cow} /$ day
}

Table 4 Prediction of FCM production over a 300 day lactation: $\mathrm{Y}=\mathrm{a}+\mathrm{bx}{ }^{0.5}, \mathrm{x}=\mathrm{kg}$ concentrate/cow/day, $r^{2}=0.37$, fitted Standard Error $=742.5$, F-value $=62.3$

\begin{tabular}{ccccccc}
\hline Parameter & Value & Std Error & t-value & 95\% Confidence limits & P $>|\mathrm{t}|$ \\
\hline a & 3742 & 134.3 & 27.9 & 3475 & 4008 & 0.0000 \\
b & 557 & 70.6 & 7.89 & 417 & 697 & 0.0000 \\
\hline
\end{tabular}

by cows fed the low ( $2.4 \mathrm{~kg})$, medium $(4.8 \mathrm{~kg})$ and high $(7.2 \mathrm{~kg}$ ) level of concentrate respectively over the two lactations. Robaina et al. (1998) reported that cows grazing on ryegrass/clover pasture that were fed 0, 1.8, 3.4 and $6.7 \mathrm{~kg}$ of concentrate per day produced 12.9, 15.7, 16.1 and $18.4 \mathrm{~kg}$ of milk per day with an average butterfat 
of $4.4 \%$.The milk response was $1.5,0.9$ and $0.82 \mathrm{~kg}$ of milk $/ \mathrm{kg}$ concentrate fed at the different concentrate levels, which is higher than that reported in our study. The genetic ability of cows to respond to concentrate feeding on a pasture based system may vary. In a study done in New Zealand it has been shown that the response to concentrate feeding was 0.63 and $0.45 \mathrm{~kg}$ milk per kg of concentrate for New Zealand Holsteins and 0.9 and 0.84 $\mathrm{kg}$ milk per $\mathrm{kg}$ of concentrate for North American Holsteins when fed 3 or $6 \mathrm{~kg}$ of concentrate per day respectively (J.R. Roche, Personal communication, e-mail: john.roche@dexcel.co.nz). Grainer \& Mathews (1989) found that the response in milk yield was $0.97,0.69$ and $0.28 \mathrm{~kg} / \mathrm{kg}$ DM concentrate fed at 3.2 $\mathrm{kg} / \mathrm{cow} /$ day when 8,17 and $33 \mathrm{~kg}$ DM of pasture was allocated per cow/day, respectively. Hoden et al. (1991) showed a return of $0.6 \mathrm{~kg}$ FCM for each $\mathrm{kg}$ of concentrate fed at $3.7 \mathrm{~kg} /$ day to high yielding dairy cows. At the higher levels of concentrate feeding the substitution rate can be expected to be high (Faverdin et al., 1991) resulting in a lower milk response to concentrate feeding. Concentrate feeding had no significant effect on the butterfat or protein content of milk over two lactations.

The live weight of cows at the start of lactation was higher for the HC treatment compared to cows on the other treatments. Cows on all treatments gained live weight during lactation. Live weight change from the start to the end of lactation did not differ between treatments. At the end of lactation the live weight and condition score of cows on the HC treatment was higher than that of cows on the NC and LC treatment. The cows on the NC treatment had a similar live weight at the end of lactation than cows on the NC and LC treatment. Regressions fitted to predict live weight and condition score using the level of concentrate feeding as independent variable had a $\mathrm{R}^{2}$ of less than 0.03 , indicating that concentrate feeding level did not affect liveweight and condition. At the start of lactation the condition score of cows on the HC treatment was higher than that of cows on the other treatments. The condition score of cows on the HC and MC treatment at the end of lactation was higher than that of cows on the NC and LC treatments. Cows on the HC treatment did not store too much energy as the condition score was 2.7 at the end of the second lactation. The condition score tended to improve as the level of concentrate feeding increased. It is to be expected that higher levels of concentrate feeding will result in a higher live weight and condition score in cows.

The cows fed no concentrate had a significantly shorter calving interval than cows fed at the high level of concentrate. The intercalving period (ICP) for cows on the LC, MC and HC did not differ from each other. Cows on the NC treatment had a shorter ICP than cows on the LC and HC treatment. Feeding no concentrate to cows for two lactations did not have a negative effect on the ICP of cows although the condition score was low at 2.1 to 2.2. The intercalving period may be affected by many factors such as calving ease, incidence of milk fever, heat observation, timing of insemination, insemination technique as well as nutrition of the cow. Keady et al. (2001) showed that concentrate supplementation in late lactation did not alter dairy cow fertility in subsequent lactations.

With the present concentrate price of $\mathrm{R} 1.60 / \mathrm{kg}$, pasture cost of $\mathrm{R} 0.40$ and milk price of $\mathrm{R} 1.80$ the margin over feed cost was R 529, R 583, R 521 and R 519/cow/month respectively on the NC, LC, MC and HC treatments respectively. The economics of concentrate feeding should be calculated on a whole farm basis. Higher levels of concentrate feeding to cows on pasture will result in higher substitution rates and require higher stocking rates to ensure effective pasture utilization (Faverdin et al., 1991).

\section{Conclusions}

The feeding of concentrates did result in increased production of milk, butterfat and protein per lactation and a higher condition score. The butterfat and protein percentage of milk was not affected by the feeding of concentrates over two lactations. Concentrate feeding did not shorten the intercalving period over two lactations. Jersey cows grazing on kikuyu, annual ryegrass, lucerne and perennial ryegrass/clover pasture produced $3742 \mathrm{~kg}$ FCM over a 300 day lactation ( $12.5 \mathrm{~kg} \mathrm{FCM/day)} \mathrm{with} \mathrm{only} \mathrm{a} \mathrm{mineral} \mathrm{supplement.} \mathrm{The} \mathrm{milk} \mathrm{response} \mathrm{per} \mathrm{kg}$ of concentrate fed was 1.25, 0.78 and $0.54 \mathrm{~kg}$ FCM in cows fed the low (2.4 kg), medium (4.8 kg) and high (7.2 $\mathrm{kg}$ ) level of concentrate respectively over two lactations. The study showed a diminishing return on concentrate feeding as the level of concentrate feeding increased. The highest margin over feed cost (R 583/cow/month) was obtained at the low level of concentrate feeding ( $2.4 \mathrm{~kg} / \mathrm{cow} / \mathrm{day})$.

\section{References}

AOAC, 1995. Official methods of analysis. (16th ed.). Association of Official Analytical Chemists. Inc., Maryland, USA. Methods 4.2.02 (954.01). 
ARC, 1984. The Nutrient Requirements of Ruminant Livestock. Agriculture Research Council, The Lavenham Press, LTD., Lavenham, Suffolk, UK. pp. 59.

Bargo, F., 2002. Feeding systems combining pasture with concentrate and total mixed rations for high producing dairy cows. PhD thesis, The Pennsylvania State University, The Graduate School College of Agricultural Sciences, University Park, P A 16802, USA.

Bargo, F., Muller, L.D., Kolver, E.S. \& Delahoy, J.E., 2003. Invited review: Production and digestion of supplemented dairy cows on pasture. J. Dairy Sci. 86, 1-42.

Giron, H.C., 1973. Atomic Absorption News Letter 12, 28.

Grainer, C. \& Mathews, G.L., 1989. Positive relation between substitution rate and pasture allowance for cows receiving concentrates. Aust. J. Exp. Agric. 29, 355-360.

Hoden, A., Peyraud, J.L., Muller, A., Delaby, L., Faverdin, P., Peccatte, J.R. \& Fargetton, M., 1991. Simplified rotational grazing management of dairy cows: Effect of rates of stocking and concentrate. J. Agric. Sci., Camb. 116, 417-428.

IDF, 1996. International Dairy Federation, Standard 141B, IDF General Secretariat, Diamant Building, Boulevard Auguste Reyers 80, 1030, Brussels, Belgium, E-mail: info@fil-idf.org.

Keady, T.W.J., Mayne, C.S., Fitzpatrick, D.A. \& McCoy, M.A., 2001. Effect of concentrate feed level in late gestation on subsequent milk yield, milk composition and fertility of dairy cows. J. Dairy Sci. 84, 14681479.

Koh, T. \& Benson, T.H., 1993. Critical re-appraisal of fluorometric method for determination of selenium in biological materials. J. Assoc. Off. Anal. Chem. 66, 4, 918-926.

Kolver, E.S., 2003. Nutritional limitations to increased production on pasture-based systems. Proc. Nutr. Soc. 62, 291-300.

King, K.R., Stockdale, C.R. \& Trigg, T.E.,1990. Influence of high energy supplements containing fatty acids on the productivity of pasture-fed dairy cows. Aust. J. Exp. Agric. 30, 11-16.

Mulvany, P., 1977. Dairy Cow Condition Scoring (Leaflet no 4468). National Institute for Research in Dairying, Shinfield, RG2 (AT, UK).

Faverdin, P., Dulphy, J.P., Coulon, J.B., Vèritè, R., Garel, J.P., Rouel, J. \& Marquis, B., 1991. Substitution of roughage by concentrates for dairy cows. Livest. Prod. Sci. 27, 137-156.

Reeves, M., Fulkerson, W.J., \& Kellaway, R.C., 1996. Forage quality of kikuyu (Pennisetum clandestinum): The effect of time of defoliation and nitrogen fertilizer application in comparison with perennial ryegrass (Lolium perenne). Aust. J. Agric. Res. 47, 1349-1359.

Robaina, A.C., Grainger, C., Moate, P., Taylor, J. \& Stewart, J., 1998. Responses to grain feeding by grazing dairy cows. Aust. J. Exp. Agric. 38, 541-549.

SAS, 1999. Statistical Analysis System user's guide (Version 9, $1^{\text {st }}$ printing, Vol. 2). SAS Institute Inc., SAS Campus Drive, Cary, N.C., USA.

Tilley, J.M. \& Terry, R.A., 1963. A two stage technique for the in vitro digestion of forage crops. J. Br. Grassl. Soc. 18, 104-111.

Underwood, E.J., 1981. The Mineral Nutrition of Livestock. The Royal Society, 6 Carlton House Terrace, London, SW1Y 5AG, UK. pp. 33-55.

Van Soest, P.J., Robertson, J.B. \& Lewis, B.A., 1991. Symposium: Carbohydrate methodology, metabolism, and nutritional implications in dairy cattle. J. Dairy Sci. 74, 3583-3597.

Weather SA, 2004. South African Weather service: www.weathersa.co.za/Climat/Climstat/GeorgeStats.jsp 